\title{
Contractors Selection Criteria Framework for Construction Project in Klang Valley
}

\author{
Mohd Shahril Zainal Abedin ${ }^{1 *}$, Siti Rashidah Mohd Nasir ${ }^{1}$, Abdullah Basri ${ }^{2}$ \\ ${ }^{1 *}$ Faculty of Civil Engineering UiTM, Shah Alam, Selangor, Malaysia. \\ ${ }^{2}$ Faculty of Architecture Planning and Surveying UiTM, Shah Alam, Selangor, Malaysia. \\ *shahrilzainalabedin@gmail.com
}

\begin{abstract}
Malaysia's construction industry is going from strength to strength, with a whole host of newlyannounced projects promising to increase activity. Moreover, the construction industry is a very important part of Malaysian economy. The country already has a lot of projects ongoing and under the pipelines, with an ever-changing urban landscape offering plenty of opportunities. The evaluation of project success and the level of success criticality in the development of construction projects in Malaysia are according to the specific requirements and priorities of different project stakeholders and varies from project to project. However, the issues related to maintenance and project functionality are of main concerned to most Government Agencies in Malaysia at the project completion stage apart from client satisfaction on the good services and excellent product deliverables. In the contractor selection stage is commonly used procedure for identifying a pool of competitive, competent and capable contractors from which tenders may be sought. It can aid public and private owners in achieving success by ensuring that only qualified contractor is selected to execute the work. The findings results indicate that several of the criteria highlighted as the most influential criteria of contractor selection for construction project. Another important understanding from the research is that the developing the framework to show the most appropriate ways to select the best contractor for the project. The weightage of each criterion are effective for assessing the technical and commercial tender submission during the tender process. Analysis indicated the top 3 of most influential criteria for contractor selection for construction project in Klang Valley are participation in stakeholders bid process, good tender proposal and method of statement.
\end{abstract}

Keywords: contractor selection criteria, construction project, performance of contractor 


\section{0 INTRODUCTION}

Construction is one of the Nation's largest industries and it is important for enhancing the industry competitiveness. By construction industry, it is give support to human activities such as shelter, industry, the safety and quality of life of the people, and environmental quality. The construction industry has many fraction which composed not only of companies that actually build structures, but also build the infrastructure to the land to be developed in a particular developing area. According to Wang (1994), as construction industry becoming more sophisticated, a more necessary approach is vital to deal with initiating, planning, financing, designing, approving, implementing and completing the project.

Besides that, construction industry is often considered as a risky business due to its complexity and strategic nature. It incurs a numerous project stakeholder, internal and external factors which will lead to enormous risks. Unfortunately, the construction industry is basically considered to have underperformed compared to the other industries such as UK construction industry has been labeled as not performing at the same level compared to other developed countries. (Takim and Akintoye, 2002).

With increasing complexity and sophisticating of construction projects, further complications have been added to the contractor selection process. This new environment of construction created a need for new methods and tools to help decision makers to make informed decisions. Evaluating the contractor's bid based on price only does not seem to satisfy decision makers anymore. (El-Abbasy et. al., 2013).

A lot of conflicting objectives and alternatives, such as tender price and non-price criteria, financial capabilities, and experience, need to be considered. Recently, to assist clients in making decisions, there has been a trend away from a "lowest-price wins" principle and subjective judgments to a multi-criteria selection approach in the selection of contractors for construction projects. Therefore, the objectives of this research are: a) To identify the main criteria, ranking and weightage in contractor selection criteria

b) To develop framework of contractor selection for the construction project.

\section{0 \\ CRITERIA AFFECTING CONTRACTOR SELECTION}

Contractor selection is a commonly used procedure for identifying a pool of competitive, competent and capable contractors from which tenders may be sought. It can aid public and private owners in achieving success by ensuring that only qualified contractor is selected to execute the work (Mills, 2011).

Cheng and $\mathrm{Li}$ (2004) concluded that, in terms of contractor selection, the performance of the project will be highly affected when inappropriate methods are used. It is presented that considering the great importance of construction projects in countries and the role of contractors as the most significant executive agents, selecting an appropriate contractor is the most important concern of clients (Bakhshi \& Bioki, 2013).

Therefore, in choosing a professional executor, the critical function is that he has unique skills and judgments. An incorrect selection may not only lead to an acrimonious contractor and client relationship but also lead the project to the failure. However, the majority of the past researchers verify that a "price-only" selection of contractor system is inefficient in choosing the most knowledgeable contractors who can execute projects profitably with winning results. Selecting the cheapest bid usually leads to delay, cost over-runs and sub-standard quality and sometimes guides the project to the failure with disputes and escalated claims, etc. (El Wardani et al., 2006; Kumaraswamy, 2006).

As part of this literature findings, the aim is to establish an overview of the selection criteria that have been conducted on this topic previously. This can serve as base point for this research. Eleven (11) academic studies are found on the subject contractor selection criteria and award criteria conducted in the last two 
decades. The categories 'Firm Characteristics' and 'Past performance \& experience' can be described as contractor selection criteria. Whereas, the categories 'Technical Bid' and 'Commercial bid' are award criteria. From this literature, it has determined the criteria to pursues in this research to structure the findings and analysis.

Based on the above, steps have been taken to provide a main and sub-criteria regarding contractor selection including four (4) main criteria which are firm characteristic, past experience and performance, commercial bid and technical bid, represent the needs for a qualified contractor to execute the project and also dividing each of the main criteria to several sub criteria.

Meanwhile, the sub-criteria includes workload capacity, financial position, health, safety and environment, key personnel, project management expertise, organizational experience, past project experience, corporation with other contractor, flexibility when resolving delays, schedule achieved on similar works, tendered price, life-cycle cost, transparency of cost data, cost savings, proposal, participation in stakeholders bid process, method statement, shortest completion date, and subcontracting strategies were respectively introduced.

From literatures findings, the main and subcriteria affecting the contractor selection are deliberated and established to adopt in this research.

\subsection{CONTRACTOR CRITERIA METHOD}

The research uses several methodologies for the prequalification process. According to Alarcon and Morgues (2002), the interfacing analysis technique offers the highest potential for the tender evaluation stage, because it reduces the possibility of rejecting a good contractor too early and offers scope for rationalization of the selection process, which is pre-qualification stage.

Many methods have been developed previously to improve the current practices of contractor selection and evaluation in many developed countries. Many tools and approaches were developed to assist decision makers in selecting the best contractors for execution of different construction projects. Simulation, Fuzzy Decision Method, and the Multicriteria Decision-Making (MCDM Analytical Hierarchy Process (AHP), Analytical Network Process (ANP), theory are examples of the approaches used to assist in making informed decisions. (El-Abbasy et al., 2013).

The consistency verification operation of AHP contributes greatly to preventing inconsistency because it acts as a feedback mechanism for the decision makers to review and revise their judgments. Consequently, the judgments made are guaranteed to be consistent, which is the basic ingredient for making good decisions and thus is considered the key reason of using the AHP method.

Additionally, most of the models have a weakness in identifying the relative weights, which usually require the relative weights to be decided in an earlier stage by other models. However, it is found that the most accurate and easy method for identifying the relative weight is AHP. Some of the above methods are based on the contractor's financial stability such models and this measurement is one of the disadvantages of the construction selection. Moreover, some models are complex and require an amount of historical data, such as Fuzzy set methods whereby in those models the user should acquire extensive mathematical background and it could be hard to collect, to understand and run the analysis. On the other hand, with the AHP just a few numbers are required.

As seen in comparison of the existing models, the AHP will be selected as the decision maker's tool. AHP can determine the best and the worst ideal solution. AHP method has shown good results in exploiting the decision information and objectively assigning weights to the primary decision attributes, especially being well applied in area of contractor selection of large scale construction projects. Further, the most positive advantage is that AHP are reliable and systematic techniques as 
they have the ability to capture an expert's judgment when complex MCDM struggles are considered (Lin et al., 2008).

Pursuing from the literatures findings, the contractor selection criteria are determined and used in this research as to reinforce the existing findings.

\subsection{RESEARCH METHODOLOGY}

To identify the importance of each criterionbeing a main or a sub criterion - in the selection process, the questionnaire used in form of pairwise comparison method. The comparison was conducted on three levels, as follows:

a) Comparison among main criteria with respect to contractor selection;

b) Comparison among sub criteria within each main criterion; and

c) Comparison among main criteria with respect to one another.

The three level of comparison to be made to create an inner interdependency between each cluster of criteria, AHP is structures a decision problem into a hierarchy with a goal, decision criteria, and alternatives, while the ANP structures it as a network. Both then use a system of pairwise comparisons to measure the weights of the components of the structure, and finally to rank the alternatives in the decision. (El-Abbasy et. al, 2010)

The aforementioned third level is one of the main features that ANP adds to the well-known AHP method, in which it allows to create an inner interdependency. The three levels can also be illustrated as shown in Fig. 1. The pair-wise comparison for each level was designed in a very simple way in which each respondent decides based on his/her own experience the degree of importance of each criterion (X) or (Y) over the other(s) with respect to the goal under question.

The degree of importance is scaled from 1-9. An assigned value of 1 indicates that there is no significant importance of a criterion over the other, whereas a value of 9 indicates that there is an absolute importance for a criterion over the other, as shown in Table 1.

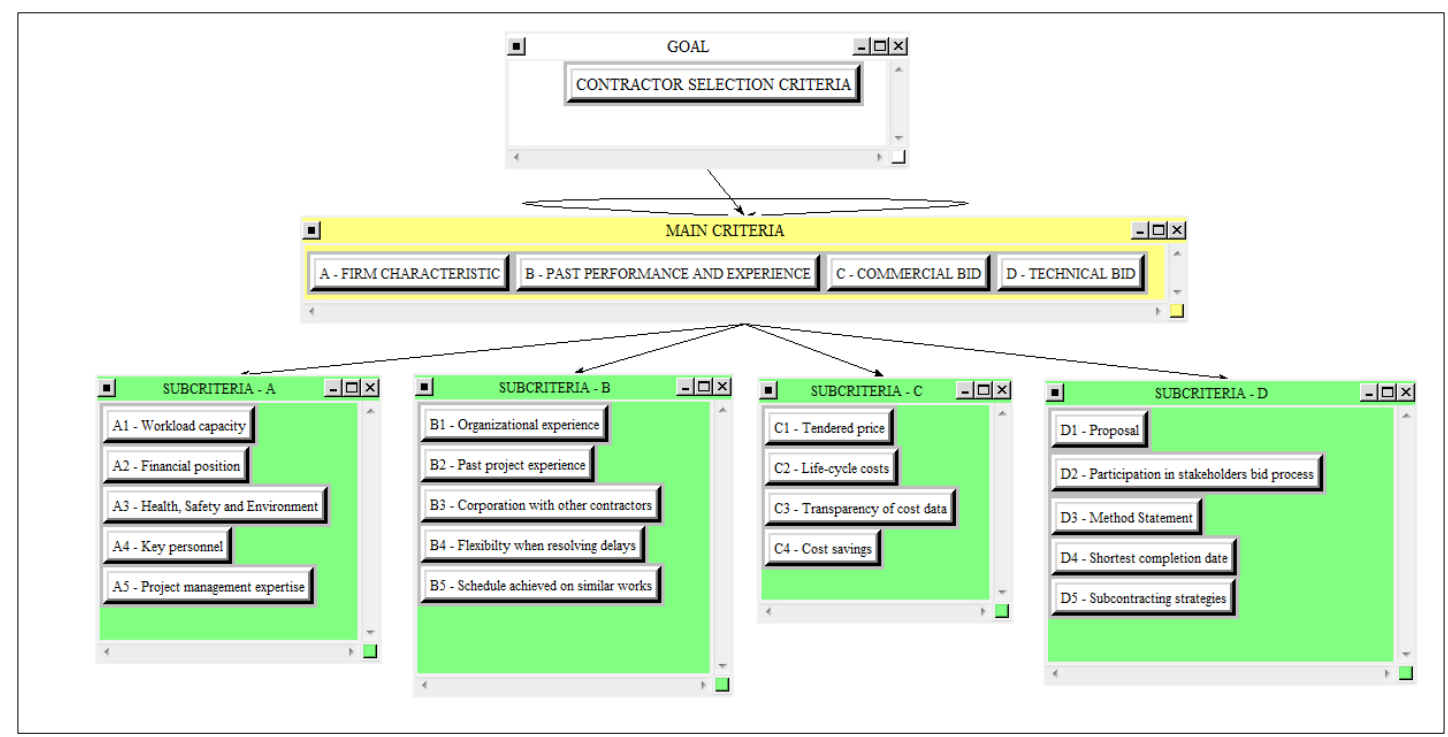

Figure 1: ANP network hierarchy by using @ Super Decision Software 
Table 1: Pair-wise comparison scale for AHP preferences (Jiang et al, 2010)

\begin{tabular}{|c|c|c|}
\hline Intensity & Definition & Explanation \\
\hline 1 & $\begin{array}{l}\text { Equal } \\
\text { importance }\end{array}$ & Two elements contribute equally to the objective \\
\hline 3 & $\begin{array}{l}\text { Moderate } \\
\text { importance }\end{array}$ & $\begin{array}{l}\text { Experience and judgement slightly favor one element over } \\
\text { another }\end{array}$ \\
\hline 5 & $\begin{array}{l}\text { Strong } \\
\text { importance }\end{array}$ & $\begin{array}{l}\text { Experience and judgement strongly favor one element over } \\
\text { another }\end{array}$ \\
\hline 7 & $\begin{array}{l}\text { Very strong } \\
\text { importance }\end{array}$ & $\begin{array}{l}\text { One element is favored very strongly over another, it dominance } \\
\text { is demonstrated in practice }\end{array}$ \\
\hline 9 & $\begin{array}{l}\text { Absolute } \\
\text { importance }\end{array}$ & $\begin{array}{l}\text { The evidence favoring one element over another is of the highest } \\
\text { possible order of affirmation }\end{array}$ \\
\hline
\end{tabular}

The steps of the ANP process were followed to determine the final global weights of selection criteria using the data collected through questionnaires. The implementation of the ANP process is briefly illustrated using the following seven steps. (El-Abbasy et.al., 2013)

1. Employing the pair-wise comparisons. The elements of each level of network hierarchy were rated using the pair-wise comparison according to Saaty's (1996) scale of measurement mentioned previously. After all elements have been compared with the priority scale pair by pair, a paired comparison matrix was developed.

2. Estimating relative weights. After the pairwise comparison matrix was developed, a vector of priorities in the matrix was calculated and then normalized to sum to 1.00 or $100 \%$. This was done by dividing the elements of each column of the matrix by the sum of that column (i.e., normalizing the column). Elements of each resulting row were added to obtain a row sum and then divided by the number of elements in the row to obtain the relative weight or priority.

3. Determining Consistency Ratio (CR). Because humans are sometimes inconsistent in answering questions, CR was used to validate the results and measure the consistency in the pair-wise comparison process. Saaty (1994) set acceptable CR values for different sizes of matrices.
4. Developing the unweighted supermatrix. With interdependent influence, the system consisting of cluster and subcluster matrices was translated into a two-dimensional supermatrix. The nodes grouped by the clusters they belong to, were the labels of rows and columns of the supermatrix. The supermatrix is not presented because of paper size limitations.

5. Developing the weighted supermatrix. The weighted supermatrix was obtained by dividing each entry in each row in the unweighted supermatrix by the total summation of its relative intersecting column.

6. Developing the limit supermatrix. After entering the submatrices into the supermatrix and completing the column to determine the weighted supermatrix, it is then raised to a sufficiently large power until convergence occurs to obtain the limit supermatrix. It is noted that the number in all columns of the limit supermatrix are identical because of convergence.

7. Calculating final global weights. From the limit super matrix, the final weights could be obtained by proportioning the elements of each cluster to themselves. To facilitate the application of the previously discussed steps, Super Decisions software was used. The network's components and relations were identified as shown in Fig. 1 and then the pair-wise comparison for each level was entered. 
This research adopts the pair-wise comparison to determine the level of intensity how the criteria selection is measured. Subsequently, Global Weight analysis is used to analyse the influential criteria's ranking over data collected from the findings.

In this research, the coding/tagging A, B, C and $\mathrm{D}$ are used to represent the most influential main criteria's ranking tabulated in Table 6 . Whereas, the coding system A1, A2, A3, 14, A5, B1, B2, B3, B4, B5, C1, C2, C3, D1, D2, D3, D5 are represent the most influential sub-Criteria's ranking in order to differentiate the normalized matrix over idealized matrix for each criteria which explained in Chapter $\mathrm{V}$ and tabulated in Table 7.

\section{0 \\ RESULTS AND DISCUSSION}

The findings on critical criteria influencing the construction project in this research is used as basis in establish the framework. The data is analysed and discussion on the findings to complement the objectives of the research. The data obtained based on the returned questionnaire survey distributed to respondents with a certain response rate. Besides that, based on the return questionnaire survey template, the respondents are classified according to their position and the working experience in the industry. The data is analysed and discusses further to give a more distinct view of issues within the construction industry.

The elements of each level of network hierarchy were rated using the pair-wise comparison scale of measurement as mentioned. Subsequently, all elements have been compared with the priority scale pair by pair, a paired comparison matrix then was developed as per Figure 2.

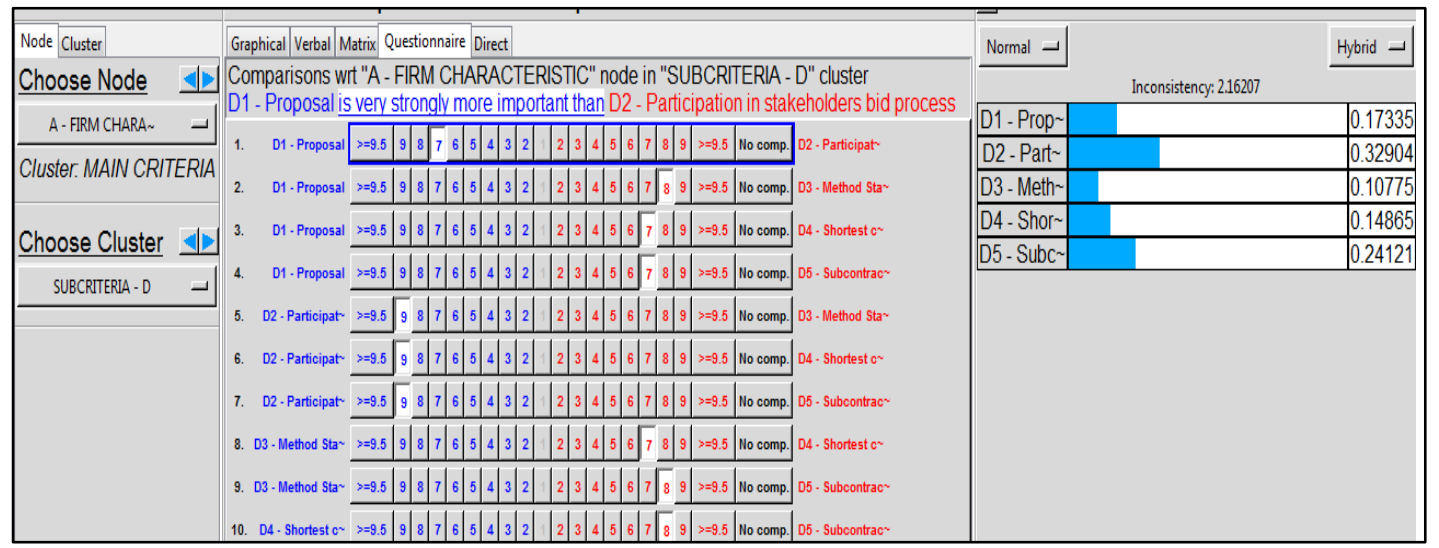

Figure 2: Part of Pair-wise comparisons process by using @ Super Decision software.

After the pair-wise comparison matrix was developed, a vector of priorities in the matrix was calculated and then normalized to sum to 1.00 or $100 \%$. This was done by dividing the elements of each column of the matrix by the sum of that column (i.e., normalizing the column). Elements of each resulting row were added to obtain a row sum and then divided by the number of elements in the row to obtain the relative weight or priority as shown in the Table 2. 
Table 2: Vector of Priorities of Criteria Normalized by Cluster

\begin{tabular}{|l|c|c|}
\hline \multicolumn{1}{|c|}{ Name } & $\begin{array}{c}\text { Normalized } \\
\text { By Cluster }\end{array}$ & Limiting \\
\hline CONTRACTOR SELECTION CRITERIA & 0 & 0 \\
A - FIRM CHARACTERISTIC & 0.02612 & 0.005224 \\
B - PAST PERFORMANCE AND EXPERIENCE & 0.07927 & 0.015854 \\
C - COMMERCIAL BID & 0.21575 & 0.04315 \\
D - TECHNICAL BID & 0.67886 & 0.135773 \\
A1 - Workload capacity & 0.35041 & 0.070082 \\
A2 - Financial position & 0.30983 & 0.061967 \\
A3 - Health, Safety and Environment & 0.31813 & 0.063626 \\
A4 - Key personnel & 0.00578 & 0.001156 \\
A5 - Project management expertise & 0.01585 & 0.00317 \\
B1 - Organizational experience & 0.48744 & 0.097487 \\
B2 - Past project experience & 0.48807 & 0.097613 \\
B3 - Corporation with other contractors & 0.00274 & 0.000548 \\
B4 - Flexibilty when resolving delays & 0.00656 & 0.001311 \\
B5 - Schedule achieved on similar works & 0.01521 & 0.003041 \\
C1 - Tendered price & 0.32531 & 0.065062 \\
C2 - Life-cycle costs & 0.3267 & 0.065339 \\
C3 - Transparency of cost data & 0.33026 & 0.066052 \\
C4 - Cost savings & 0.01773 & 0.003546 \\
D1 - Proposal & 0.248 & 0.0496 \\
D2 - Participation in stakeholders bid process & 0.25206 & 0.050413 \\
D3 - Method Statement & 0.24628 & 0.049257 \\
D4 - Shortest completion date & 0.24735 & 0.049471 \\
D5 - Subcontracting strategies & 0.0063 & 0.00126 \\
& & \\
\hline
\end{tabular}

$\mathrm{CR}$ was used to validate the results and measure the consistency in the pair-wise comparison process. The CR values were calculated for all matrices, which showed all of them to be consistent within the range of 0.00274 to
0.67886. The Table 3 shows how the inconsistency in the answering the questions solved by conducting normalization and idealization process.

Table 3: The result and measure the consistency in the pair-wise comparison process

\begin{tabular}{|c|c|c|}
\hline Inconsistency & 0.470 & \\
\hline $\begin{array}{l}\text { Name } \\
\text { A - FIRM CHARACTERISTIC } \\
\text { B - PAST PERFORIMANCE AND EXPERIENCE } \\
\text { C - COMMMERCIAL BID } \\
\text { D - TECHNICAL BID }\end{array}$ & $\begin{array}{l}\text { Normalized } \\
0.026120178 \\
0.079268052 \\
0.215747839 \\
0.678863932\end{array}$ & $\begin{array}{c}\text { Idealized } \\
0.03847631 \\
0.11676574 \\
0.31780719 \\
1\end{array}$ \\
\hline Inconsistency & 0.27 & \\
\hline $\begin{array}{l}\text { Name } \\
\text { A1 - Workload capacity } \\
\text { A2 - Financial position } \\
\text { A3 - Health, Safety and Environment } \\
\text { A4 - Key personnel } \\
\text { A5 - Project management expertise }\end{array}$ & $\begin{array}{l}\text { Normalized } \\
0.025950999 \\
0.027278884 \\
0.095762813 \\
0.218170408 \\
0.632836896\end{array}$ & $\begin{array}{c}\text { Idealized } \\
0.04100741 \\
0.04310571 \\
0.15132306 \\
0.34474982 \\
1\end{array}$ \\
\hline Inconsistency & 0.452 & \\
\hline $\begin{array}{l}\text { Name } \\
\text { B1 - Organizational experience } \\
\text { B2 - Past project experience } \\
\text { B3 - Corporation with other contractors } \\
\text { B4 - Flexibilty when resolving delays } \\
\text { B5 - Schedule achieved on similar works }\end{array}$ & $\begin{array}{l}\text { Normalized } \\
0.018997522 \\
0.04307035 \\
0.104852584 \\
0.250942472 \\
0.582137072\end{array}$ & $\begin{array}{c}\text { Idealized } \\
0.0326341 \\
0.07398661 \\
0.18011666 \\
0.43107111 \\
1\end{array}$ \\
\hline Inconsistency & 0.470 & \\
\hline $\begin{array}{l}\text { Name } \\
\text { C1 - Tendered price } \\
\text { C2 - Life-cycle costs } \\
\text { C3 - Transparency of cost data } \\
\text { C4 - Cost savings }\end{array}$ & $\begin{array}{l}\text { Normalized } \\
0.026120178 \\
0.079268052 \\
0.215747839 \\
0.678863932\end{array}$ & $\begin{array}{c}\text { Idealized } \\
0.03847631 \\
0.11676574 \\
0.31780719 \\
1\end{array}$ \\
\hline Inconsistency & 2.162 & \\
\hline $\begin{array}{l}\text { Name } \\
\text { D1 - Proposal } \\
\text { D2 - Participation in stakeholders bid process } \\
\text { D3 - Method Statement } \\
\text { D4 - Shortest completion date } \\
\text { D5 - Subcontracting strategies }\end{array}$ & $\begin{array}{l}\text { Normalized } \\
0.173347382 \\
0.329040424 \\
0.107753704 \\
0.148648903 \\
0.241209588\end{array}$ & $\begin{array}{c}\text { Idealized } \\
0.52682701 \\
1 \\
0.32747862 \\
0.45176486 \\
0.73306977\end{array}$ \\
\hline
\end{tabular}


The result shows that the different of matrix between normalized matrix over idealized matrix for each main criteria and sub-criteria. The inconsistencies are within range of 0.2727 to 2.16207. The sub-criteria A5, B5, C4 and D2 shows balance of consistency with the matrix of 1 respectively. It shows that those criteria most selected by the respondent as the most influential criteria for each sub-criteria.
After entering the submatrices into the supermatrix and completing the column to determine the weighted supermatrix, it is then raised to a sufficiently large power until convergence occurs to obtain the limit supermatrix. Table 4 show that the number in all columns of the limit super matrix are identical because of convergence. Refer to Appendix $\mathrm{C}$ for complete set of several of supermatrix of this research.

Table 4: Part of Various Types of Supermatrix

\begin{tabular}{|c|c|c|c|c|c|c|c|c|c|c|c|c|c|c|c|c|}
\hline \multirow{3}{*}{\multicolumn{2}{|c|}{ With respect to }} & \multicolumn{5}{|c|}{ Unweighted supermatrix } & \multicolumn{5}{|c|}{ Weighted supermatrix } & \multicolumn{5}{|c|}{ Limit supermatrix } \\
\hline & & \multicolumn{5}{|c|}{ Main Criteria } & \multicolumn{5}{|c|}{ Main Criteria } & \multicolumn{5}{|c|}{ Main Criteria } \\
\hline & & Goal & A & $B$ & $\mathrm{c}$ & D & Goal & A & $B$ & $\mathrm{c}$ & D & Goal & A & $B$ & $\mathrm{c}$ & D \\
\hline Goal & & .000000 & 000000 & 0.000000 & 000000 & 000000 & 0.0000000 & 100000 & 0.000000 & 00000 & 0.000000 & 0.0000000 & 000000 & 000000 & 0.000000 & 000000 \\
\hline \multirow[t]{4}{*}{ Main Criteria } & A & 028120 & 00 & 0.000000 & 00000 & 00 & 26120 & 000 & 0.000000 & 00000 & 0.000000 & 0.005224 & 0.200000 & & 0.000000 & \\
\hline & B & 079288 & 000000 & 1.000000 & 0.000000 & 000000 & 079288 & 100000 & 0.200000 & 0.000000 & 0.000000 & 0.015854 & 0.000000 & 0.200000 & 0.000000 & 0.000000 \\
\hline & $c$ & 0.215748 & 0.000000 & 0.000000 & 00000 & 00000 & 15748 & 00000 & 0.000000 & 0.200000 & 0.000000 & 0.043150 & & 0.000000 & 0.200000 & 0.000000 \\
\hline & D & 0.678864 & 0.000000 & 0.000000 & 0.000000 & 0.200000 & 678884 & 100000 & 0.000000 & 0.000000 & 0.200000 & 0.135773 & 0.000000 & 0.000000 & 0.000000 & 0.200000 \\
\hline \multirow[t]{5}{*}{ Subcriteria (A) } & A1 & 0.000000 & 0.000000 & 0.652174 & 0.068687 & 0.068687 & 0.000000 & 038800 & 0.130435 & 0.086687 & 0.066887 & 0.070082 & 0.003880 & 0.130436 & 0.068687 & 0.088687 \\
\hline & $\mathrm{A}_{2}$ & 0.000000 & 0.049503 & 0.130435 & 068667 & 0.088687 & 000000 & 00901 & 0.028087 & 0.086687 & 0.066887 & 0.061867 & 0.009901 & 0.026087 & 0.068687 & 0.068687 \\
\hline & $\mathrm{A}_{3}$. & 0.000000 & 0.103045 & 0.217391 & 0.068667 & 0.068667 & 000000 & 120009 & 0.043478 & 0.068687 & 0.066887 & 0.063626 & 0.020009 & 3478 & 0.086887 & 0.088667 \\
\hline & $\mathrm{A4}$ & 0.000000 & 0.221275 & 0.000000 & 100000 & 000000 & 000000 & & 0.000000 & 000000 & 000000 & 156 & & & 0.000000 & 0.000000 \\
\hline & A5 & 0.000000 & 0.608729 & 0.000000 & 0.000000 & 0.000000 & 000000 & 846 & 0.000000 & 0.000000 & 0.000000 & 0.003170 & 0.12 & 0.000000 & 0.000000 & 0.000000 \\
\hline \multirow[t]{5}{*}{ Subcriteria (B) } & B1 & 0.000000 & 0.018998 & 0.500000 & 100000 & 100000 & 000000 & 00 & 0.100000 & 100 & 00000 & 87 & & & 0.100000 & 0.100000 \\
\hline & B2 & 0.000000 & 043070 & 0.500000 & 1.000000 & 0.100000 & 000000 & 088614 & 0.100000 & 0.100000 & 0.100000 & 0.097613 & 0.008614 & 0.100000 & 0.100000 & 0.100000 \\
\hline & $\mathrm{B}_{3}$ & 0.000000 & 0.104853 & 0.000000 & 0.000000 & 0.000000 & 000000 & 20071 & 0.000000 & 0.000000 & 0.000000 & 48 & 71 & 0.000000 & 0.000000 & 0.00000 \\
\hline & B4 & 0.000000 & 0.250942 & 0.000000 & 0.000000 & 0.000000 & 0.000000 & 160188 & 0.000000 & 0.000000 & 0.000000 & 0.001311 & 0.060188 & 0.000000 & 0.000000 & 0.00000 \\
\hline & B5 & 0.000000 & 0.582137 & 0.000000 & 0.000000 & 0.000000 & 0.000000 & 16427 & 0.000000 & 0.000000 & 0.000000 & 041 & 0.116427 & 0.000000 & 0.000000 & 0.00000 \\
\hline \multirow[t]{4}{*}{ Subcriteria (C) } & C1 & 0.000000 & 028120 & 0.333300 & 0.068667 & 0.068687 & 0.000000 & 24 & 0.068667 & 0.086687 & 0.066887 & 0.065061 & 0.005224 & 0.086867 & 0.068687 & 0.06868 \\
\hline & $\mathrm{C} 2$ & 0.000000 & 0.079288 & 0.333300 & 0.068687 & 68687 & 100000 & 64 & 0.080 & 0.068687 & & 339 & & & .08688 & 0.06866 \\
\hline & $\mathrm{C} 3$ & 0.000000 & 48 & 0.333300 & 0.068667 & 0.068687 & 0.000000 & & 0.068667 & 0.068687 & 0.066887 & 62 & 0.04 & & 0.066687 & 0.06868 \\
\hline & $\mathrm{C4}$ & 0.000000 & 0.678864 & 0.000000 & 0.000000 & 0.000000 & 0.000000 & 135773 & 0.000000 & 0.000000 & 0.000000 & 03548 & 0.135773 & 0.000000 & 0.000000 & 0.00000 \\
\hline \multirow[t]{5}{*}{ Subcriteria (D) } & D1 & 0.000000 & 0.173 & 0.250000 & 0.050000 & 0.050000 & 0.000000 & 88 & 0.050000 & 0.050000 & 050000 & 300 & 0.03 & 00 & 0.050000 & 0.05000 \\
\hline & $\mathrm{D} 2$ & 0.000000 & 0.328040 & 0.250000 & 0.050000 & 0.050000 & 0.000000 & 085808 & 0.050000 & 0.050000 & 50000 & 13 & 0.005808 & 1500000 & 0.050000 & 0.05000 \\
\hline & $D_{3}$ & 0.000000 & 0.107754 & 0.250000 & 0.050000 & 0.050000 & 0.000000 & 51 & 0.050000 & 0.050000 & 0.050000 & 0.048257 & 0.021551 & 0.050000 & 0.050000 & 0.05000 \\
\hline & D4 & 0.000000 & & 0.250000 & 0.050000 & 0.050000 & 0.000000 & 0.029730 & 0.050000 & 0.050000 & 0.050000 & & 0.028730 & 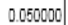 & 0.050000 & 0.05000 \\
\hline & D5 & 0.000000 & 0.241210 & 0.000000 & 0.000000 & 0.000000 & 0.000000 & 0.048242 & 0.050000 & 0.000000 & 0.000000 & 0.001280 & 0.048242 & 0.000000 & 0.000000 & 0.0000 \\
\hline
\end{tabular}

The result shows that goal matrices in the row of limit supermatrix will get the total value of 1 , which is to predetermine the local weightage for each main criteria and sub-criteria. The highest limit supermatrix is for main criteria D (commercial bid) and the range highest value of 0.001156 (corporation with other contractors) to lowest value of 0.097487 (past project performance).

From the limit super matrix, the final weights could be obtained by proportioning the elements of each cluster to themselves. To facilitate the application of the previously discussed steps, @Super Decisions software was used. The network's components and relations were identified and then the pair-wise comparison for each level was entered.
As shown in Table 5, the cluster of main criteria is contractor's firm characteristic, past experience and performance, technical bid and commercial bid with matrix values of 0.005224 , 0.015854, 0.043150, and 0.135773, respectively, which results in a total matrix value of 0.20 . Therefore, all matrices were calculated by divided each of these values by 0.20 for the final matrix weights.

The same procedure was followed with each sub criteria cluster to obtain the local weight, which was then multiplied by the final weights of each corresponding main criteria to obtain the global weight. 
Table 5: Average Final Local and Global Weights for Main and Sub criteria

\begin{tabular}{|c|c|c|c|c|c|c|}
\hline Main Criteria & Global Weight (\%) & & & Subcriteria & Local weight (\%) & Global weights (\%) \\
\hline (A) Firm Characteristic & 2.61 & $\begin{array}{l}\text { A1 } \\
\text { A2 } \\
\text { A3 } \\
\text { A4 } \\
\text { A5 }\end{array}$ & $\begin{array}{l}\vdots \\
\vdots \\
\vdots \\
\vdots\end{array}$ & $\begin{array}{c}\text { Workload Capacity } \\
\text { Financial Position } \\
\text { Health, Safety and Environment } \\
\text { Key Personnel } \\
\text { Management Personnel }\end{array}$ & $\begin{array}{c}31.0 \\
31.8 \\
0.6 \\
1.6 \\
48.7\end{array}$ & $\begin{array}{l}0.92 \\
0.81 \\
0.83 \\
0.02 \\
0.04\end{array}$ \\
\hline $\begin{array}{l}\text { (B) Past Experience \& } \\
\text { Performance }\end{array}$ & 7.93 & $\begin{array}{l}\text { B1 } \\
\text { B2 } \\
\text { B3 } \\
\text { B4 } \\
\text { B5 }\end{array}$ & $\begin{array}{l}\vdots \\
\vdots \\
\vdots \\
\vdots\end{array}$ & $\begin{array}{c}\text { Organizational Experience } \\
\text { Past Project Performance } \\
\text { Corporation when resolving delay } \\
\text { Corporation with other contractors } \\
\text { Schedule achieved on similar works }\end{array}$ & $\begin{array}{c}1.6 \\
48.7 \\
48.8 \\
0.3 \\
0.7\end{array}$ & $\begin{array}{l}3.86 \\
3.87 \\
0.02 \\
0.05 \\
0.12\end{array}$ \\
\hline (C) Technical Bid & 21.58 & $\begin{array}{l}\text { C1 } \\
\text { C2 } \\
\text { C3 } \\
\text { C4 }\end{array}$ & $\begin{array}{c} \\
\vdots \\
\vdots \\
\vdots\end{array}$ & $\begin{array}{c}\text { Tendered Price } \\
\text { Life Cycle Costing } \\
\text { Transparency of cost data } \\
\text { Cost saving }\end{array}$ & $\begin{array}{c}32.5 \\
32.7 \\
33.0 \\
1.8\end{array}$ & $\begin{array}{l}7.02 \\
7.05 \\
7.13 \\
0.38\end{array}$ \\
\hline (D) Commercial Bid & 67.89 & $\begin{array}{l}\text { D1 } \\
\text { D2 } \\
\text { D3 } \\
\text { D4 } \\
\text { D5 }\end{array}$ & $\begin{array}{l}\vdots \\
\vdots \\
\vdots \\
\vdots\end{array}$ & $\begin{array}{c}\text { Proposal } \\
\text { Participation in stakeholders bid process } \\
\text { Method statement } \\
\text { Shortest completion period } \\
\text { Subcontracting strategies }\end{array}$ & $\begin{array}{c}24.8 \\
25.2 \\
24.6 \\
24.7 \\
0.6\end{array}$ & $\begin{array}{c}16.84 \\
17.11 \\
16.72 \\
16.79 \\
0.43\end{array}$ \\
\hline
\end{tabular}

The result shows the local and global weights of each main criteria and sub-criteria for contractor selection. The high weightage represents the importance of that criterion compared to the others in selecting the best contractor for the project. Meanwhile, the low weightage represents the least importance, but the client should not hinder that criterion at all, but give some consideration to the contractors who least convincing on the area of evaluation, by contradict to their less convincing result to their technical and commercial bid in the same time.

Based on the result of global weight of each main criterion, the main criteria which has highest global weight is commercial bid
(67.89\%), follow by technical bid (21.58\%), past experience and performance $(7.93 \%)$, and firm characteristic $(2.61 \%)$. The sub-criteria which among the highest global weight are participation of in shareholders bid process (17.11\%), followed by proposal (16.84), shortest completion period $(16.79 \%)$, method statement $(16.72 \%)$, transparency of cost data $(7.13 \%)$, life-cycle costing $(7.05 \%)$, tendered price $(7.02 \%)$, project past experience $(3.87 \%)$, and organizational experience $(3.86 \%)$.

The brief explanation on every main criteria and sub-criteria are described, simplified and ranked as Table 6 and Table 7 respectively.

Table 6: The Most Influential Main Criteria’s ranking

\begin{tabular}{|c|c|l|c|c|}
\hline No. & $\begin{array}{c}\text { Main } \\
\text { Criteria }\end{array}$ & $\begin{array}{c}\text { Global } \\
\text { Weight (\%) }\end{array}$ & Ranking \\
\hline D & $\begin{array}{c}\text { Commercial } \\
\text { Bid }\end{array}$ & $\begin{array}{l}\text { Focus on the competitiveness of price } \\
\text { offered value management and cost } \\
\text { saving, and commercial value of the } \\
\text { proposal. }\end{array}$ & $\mathbf{6 7 . 8 9}$ & $\mathbf{1}$ \\
\hline $\mathbf{C}$ & $\begin{array}{c}\text { Technical } \\
\text { Bid }\end{array}$ & $\begin{array}{l}\text { Focus on the technical capabilities, } \\
\text { number of resources, commitment to } \\
\text { fulfill client requirements, and } \\
\text { promising tendency to perform well } \\
\text { in the project. }\end{array}$ & $\mathbf{2 1 . 5 8}$ & $\mathbf{2}$ \\
\hline $\mathbf{B}$ & $\begin{array}{c}\text { Past } \\
\text { Experience }\end{array}$ & $\begin{array}{l}\text { Focus on the overall performance of } \\
\text { previous project which is similar in } \\
\text { nature to the proposed project and } \\
\text { potential for future projects. }\end{array}$ & $\mathbf{7 . 9 3}$ & $\mathbf{3}$ \\
\hline $\mathbf{A}$ & $\begin{array}{c}\text { Firm } \\
\text { Characterist } \\
\text { ic }\end{array}$ & $\begin{array}{l}\text { Focus on the establishment of } \\
\text { tenderers in the construction work } \\
\text { industry, current workload, financial } \\
\text { capabalities and company reputation. }\end{array}$ & $\mathbf{2 . 6 1}$ & $\mathbf{4}$ \\
\hline
\end{tabular}


Table 7: The Most Influential Sub-Criteria's Ranking

\begin{tabular}{|c|c|c|c|c|}
\hline No. & Sub-Criteria & Explanation & $\begin{array}{c}\text { Global } \\
\text { Weight } \\
(\%)\end{array}$ & Ranking \\
\hline D2 & $\begin{array}{l}\text { Participation in stakeholders } \\
\text { bid process }\end{array}$ & $\begin{array}{l}\text { The tenderers show high commitment in the bid process, } \\
\text { and the proposal offered initiating the beneficial to the } \\
\text { client and other stakeholder in the project. }\end{array}$ & 17.11 & 1 \\
\hline D1 & Proposal & $\begin{array}{l}\text { The tenderers offer the detail proposal of site } \\
\text { organizational and work program, including proper site } \\
\text { planinng, safety policy, and quality control and } \\
\text { assurance procedures. }\end{array}$ & 16.84 & 2 \\
\hline D3 & Method statement & $\begin{array}{l}\text { The tenderers provide detail approved method of } \\
\text { statement and specification for every works and trades } \\
\text { involved in the proposed project. }\end{array}$ & 16.72 & 3 \\
\hline C3 & Transparency of cost data & $\begin{array}{l}\text { The tenderers offer their best competitive prices which is } \\
\text { no additional hidden cost, highlighted the missing items } \\
\text { to client and cost it wisely. }\end{array}$ & 7.13 & 4 \\
\hline $\mathrm{C2}$ & Life cycle costing & $\begin{array}{l}\text { The tenderers proposed their best alternative material and } \\
\text { method, which is could contribute to less cost of } \\
\text { maintenance of works after completion. }\end{array}$ & 7.05 & 5 \\
\hline C1 & Tendered price & $\begin{array}{l}\text { The tenderers offer their best competitive prices which is } \\
\text { highly reasonable and accurate to current market rate. }\end{array}$ & 7.02 & 6 \\
\hline B2 & Past project performance & $\begin{array}{l}\text { The tenderers have good track record which is completed } \\
\text { the works within stipulated reasonable time and cost. }\end{array}$ & 3.87 & 7 \\
\hline A1 & Workload capacity & $\begin{array}{l}\text { The tenderers have current project which are the value of } \\
\text { works is higher than proposed project }\end{array}$ & 0.92 & 8 \\
\hline A3 & Health Safety Environment & $\begin{array}{l}\text { The tenderers have proper health, safety and } \\
\text { environment policies and procedures, supported with } \\
\text { quality assurance certification. }\end{array}$ & 0.83 & 9 \\
\hline A2 & Financial Position & $\begin{array}{l}\text { The tenderers achieved highly turnover rate within past } \\
\text { three years, good current financial standing and credit } \\
\text { facilities. }\end{array}$ & 0.81 & 10 \\
\hline D5 & Subcontracting strategies & $\begin{array}{l}\text { The tenderers proposed the best subcontracting and } \\
\text { procurement strategies, which could contribute to cost } \\
\text { saving to client and shorter duration of works. }\end{array}$ & 0.43 & 11 \\
\hline $\mathrm{C4}$ & Cost saving & $\begin{array}{l}\text { The tenderers proposed their best alternative material and } \\
\text { method, which is could contribute to cost reduction and } \\
\text { value for money to the client }\end{array}$ & 0.38 & 12 \\
\hline B5 & $\begin{array}{l}\text { Schedule achieved on similar } \\
\text { works }\end{array}$ & $\begin{array}{l}\text { The tenderers have good record in completing the works } \\
\text { without delay in previous works which is similar in } \\
\text { nature. }\end{array}$ & 0.12 & 13 \\
\hline B4 & $\begin{array}{l}\text { Corporation with other } \\
\text { contractors }\end{array}$ & $\begin{array}{l}\text { The tenderers have good record and relationship with } \\
\text { previous other contractor in the same project, resulting } \\
\text { smooth project delivery. }\end{array}$ & 0.05 & 14 \\
\hline A5 & Management personnel & $\begin{array}{l}\text { The tenderers proposed the technically competence } \\
\text { project management team for the proposed project }\end{array}$ & 0.04 & 15 \\
\hline A4 & Key Personnel & $\begin{array}{l}\text { The tenderers proposed the highly qualified and } \\
\text { experienced person as project manager for the proposed } \\
\text { project. }\end{array}$ & 0.02 & 16 \\
\hline B3 & $\begin{array}{l}\text { Corporation when resolving } \\
\text { delay }\end{array}$ & $\begin{array}{l}\text { The tenderers have good record and relationship with } \\
\text { other previous clients, resulting successful completion of } \\
\text { works without delay. }\end{array}$ & 0.02 & 17 \\
\hline
\end{tabular}


From the Global Weight analysis, it reveals that the most criteria incline to be adopted in selection criteria is the participation in stakeholders bid process which contributes to $17.11 \%$ followed by proposal and method statement. Hence, the commitments demonstrated by the tenderer winning the tender is the most concerns in the selection criteria.

The final objective of this research is to develop suitable framework in order to obtain the systematic approach in the contractor selection.
The common practice in the client's office is to have the simple comparison based on the experience and the price offered by the contractor in the tender process, instead to have the reliable weightage of criteria in their evaluation and assessment of the contractors. From the findings and discussion, the systematic Framework is established in each stages of assessment as a guiding tools in selecting the most appropriate contractor with the lowest bidding price for the construction industry.

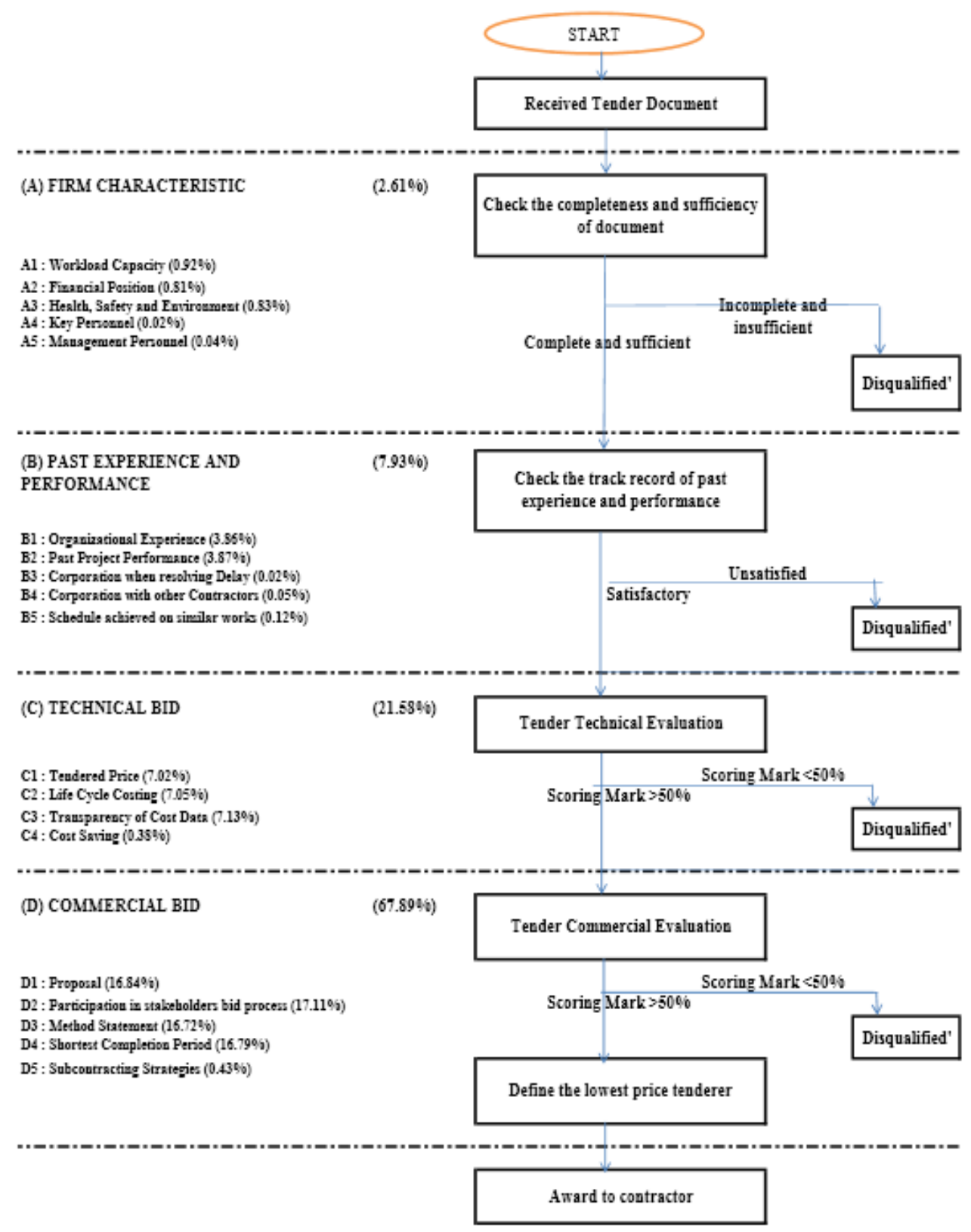




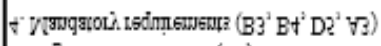

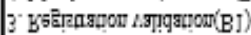

İ I

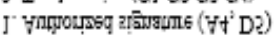

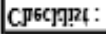

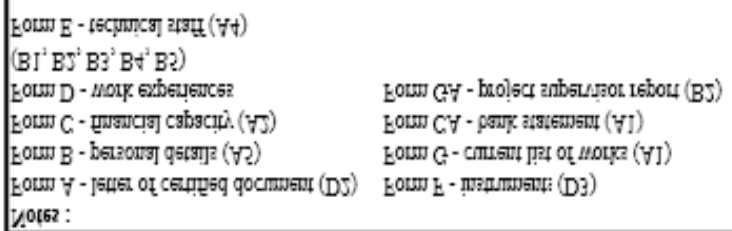

Figure 3: The framework for contractor selection

\subsection{CONCLUSION}

The finding results indicate that several of the criteria highlighted as the most influential criteria of contractor selection for construction project. Another important understanding from the research is that the developing the framework to show the most appropriate ways to select the best contractor for the project. The weightage of each criterion are effective for assessing the technical and commercial tender submission during the tender process.

Analysis indicated the top 10 of most influential criteria for contractor selection for construction project in Klang Valley as following:

i. Participation in stakeholders bid process

ii. Proposal

iii. Method Statement

iv. Transparency of cost data

v. Life Cycle Costing

vi. Tendered Price

vii. Past project performance

viii. Workload Capacity

ix. Health, Safety and Environment

x. Financial position

It is also understood that all responsible parties' plays an important role to ensure the awarded contractor could deliver the project to the specified time, quality, and cost as the client requirement. Out of various criteria considered in the research, all parties should give feedback on the result of contractor's performance in their project, so that the input would become the reference for their future projects.

\subsection{RECOMMENDATION}

Based on the conclusion of this research, the recommendation for future research shall take much wider approach especially in term of data collection and results analysis for future research, several recommendations are made. First, expand the distribution of questionnaire to wider area of research. Therefore, future studies of contractor selection criteria should utilize adequate sample sizes of the respondent to achieve accurate data to analyze. Secondly, larger sample sizes from different type of project such as infrastructure, power plant, offshore and marine structure, and etc.

Another recommendation is in term of data collection which is can be improved by online survey software as an interactive tool for editing and analyzing all sorts of data and feedback such as using Statistical Package for the Social Sciences (SPSS). Lastly, to achieve a better understanding on the contractor selection criteria and to conclude in more meticulous way, careful planning and organizing the questionnaire structure is the most important stage to get the most reliable result of the research. As a conclusion, for further research could be pursued by replicating this reseach in other type of project using more comprehensive research methodology.

\subsection{ACKNOWLEDGEMENT}

The authors gratefully acknowledge the support from Dr. Siti Rashidah Mohd Nasir. 
Wang T. H. (1994). "The Malaysian Construction Industry, its trend of growthpast, present \& Future." The Master Builders Journal, pp 3-7

Takim, R. \& Akintoye, A (2002). "Performance indicators for successful construction project performance". In: Greenwood, $\mathrm{D}$ (Ed.), $18^{\text {th }}$ Annual ARCOM Conference, 2-4 September 2002, University of Nurthumbria, Association of Researchers in Construction Management, Vol. 2, 54555.

El-Abbasy, M. S., Zayed T., Ahmed M., Alzraiee H., Abouhamad M., (2013).' Contractor Selection Model for Highway Project Using Integrated Simulation and Analytic Network Process". Journal of Construction Engineering and Management, 2013, 139(7):755-767.

Mills, A. J., (2011). The impact of client attitudes on the selection of contractors. Malaysian Construction Research Journal, 1(8), pp. 88-102.

Cheng, E. W. L. \& Li, H., (2004). Contractor selection using the analytic network process. Construction Management and Economics, 22(10), p. 1021-1032.

Bakhshi, M. \& Bioki, T. A., (2013). The New Integrated Approach for Contractor Selection Criteria. Reef Resources Assessment and Management Technical Paper, 38(5), pp. 582-596.

Kumaraswamy M, Chan D.(1998). Contributors to construction delay. Construct Manage Econom 1998;16(1):1729.

El-Wardani, M. A., Messner, J. I. \& Horman, M. J., (2006). Comparing procurement methods for design-build projects. Journal, 132(3), pp. 230-238.
Alarcon L. F. and Mourgues C. (2002). "Performance Modelling for Contractor Selection". Journal of Management and Engineering, 2002, 18(2); 52-60

Lin S. C. J., Ali A. S., Alias A. (2015). "Analytic Hierarchy Process DecisionMaking Framework for Procurement Strategy Selection in Building Maintenance Work". Journal of Performance of Construction Facilities. 2015, 29(2): 04014050

Jiang, Z. C. \& Yan, Z., 2010. Application of TOPSIS Analysis Method Based on AHP in Bid Evaluation of Power Equipment, Beijing, China: IEEE.

Saaty, T. (1994). "How to make a decision: The analytic hierarchy process. Interfaces, 24(6), 19-43.

Saaty, T. (1996). Decision making with dependence and feedback: The analytic network process, RWS, Pittsburgh. 